\title{
Regulation of metabolic transcriptional co-activators and transcription factors with acute exercise
}

Citation for published version (APA):

Russell, A. P., Hesselink, M. K., Lo, S. K., \& Schrauwen, P. (2005). Regulation of metabolic transcriptional co-activators and transcription factors with acute exercise. Faseb Journal, 19(8), 986-988. https://doi.org/10.1096/fj.04-3168fje

Document status and date:

Published: 01/01/2005

DOI:

10.1096/fj.04-3168fje

Document Version:

Publisher's PDF, also known as Version of record

Document license:

Taverne

Please check the document version of this publication:

- A submitted manuscript is the version of the article upon submission and before peer-review. There can be important differences between the submitted version and the official published version of record.

People interested in the research are advised to contact the author for the final version of the publication, or visit the DOI to the publisher's website.

- The final author version and the galley proof are versions of the publication after peer review.

- The final published version features the final layout of the paper including the volume, issue and page numbers.

Link to publication

\footnotetext{
General rights rights.

- You may freely distribute the URL identifying the publication in the public portal. please follow below link for the End User Agreement:

www.umlib.nl/taverne-license

Take down policy

If you believe that this document breaches copyright please contact us at:

repository@maastrichtuniversity.nl

providing details and we will investigate your claim.
}

Copyright and moral rights for the publications made accessible in the public portal are retained by the authors and/or other copyright owners and it is a condition of accessing publications that users recognise and abide by the legal requirements associated with these

- Users may download and print one copy of any publication from the public portal for the purpose of private study or research.

- You may not further distribute the material or use it for any profit-making activity or commercial gain

If the publication is distributed under the terms of Article $25 \mathrm{fa}$ of the Dutch Copyright Act, indicated by the "Taverne" license above, 
The FASEB Journal express article 10.1096/fj.04-3168fje. Published online April 6, 2005.

\title{
Regulation of metabolic transcriptional co-activators and transcription factors with acute exercise
}

\author{
Aaron P. Russell,* Matthijs K. C. Hesselink, ${ }^{\dagger}$ Sing Kai Lo, ${ }^{\ddagger}$ Patrick Schrauwen ${ }^{\S}$
}

*Clinique Romande de Réadaptation SUVA Care, Sion, Switzerland; 'Department of Movement Sciences, Maastricht University, The Netherlands; ${ }^{\ddagger}$ Institute for International Health, University of Sydney, Australia; and ${ }^{\S}$ Department of Human Biology, Maastricht University, The Netherlands

Corresponding author: Aaron P. Russell, Clinique Romande de Réadaptation, Case postale 352, Av. Gd-Champsec 90, 1951 Sion, Switzerland. E-mail: aaron.russell@crr-suva.ch

\section{ABSTRACT}

Endurance exercise improves insulin sensitivity and increases fat oxidation, which are partly facilitated by the induction of metabolic transcription factors. Next to exercise, increased levels of FFA's also increase the gene expression of transcription factors, hence making it difficult to discern the effects from contractile signals produced during exercise, from those produced by increased circulatory FFA's. We aimed to investigate, in human skeletal muscle, whether acute exercise affects gene expression of metabolic transcriptional co-activators and transcription factors, including PGC- $1 \alpha$, PRC, PPAR $\alpha, \beta / \delta$, and $\gamma$ and RXR, SREBP- $1 \mathrm{c}$ and FKHR, and to discern the effect of exercise per se from those of elevated levels of FFA. Two hours of endurance exercise was performed either in the fasted state, or following carbohydrate ingestion prior to and during exercise, thereby blunting the fasting-induced increase in FA availability and oxidation. Of the genes measured, PGC- $1 \alpha$ and PRC mRNA increased immediately after, while PPAR $\beta / \delta$ and FKHR mRNA increased $1-4 \mathrm{~h}$ after exercise, irrespective of the increases in FFA's. Our results suggest that the induction in vivo of metabolic transcription factors implicated in mitochondrial biogenesis are under the control of inherent signals, (PGC-1 $\alpha$, PRC), while those implicated in substrate selection are under the control of associated signals (PPAR $\beta / \delta$, FKHR) stimulated from the contracting skeletal muscle that are independent of circulating FFA levels.

Key words: PGC-1 $\alpha \cdot \mathrm{PPAR} \cdot \mathrm{SREBP}-1 \mathrm{c} \cdot \mathrm{FKHR} \cdot \mathrm{MCIP} 1$

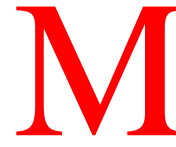
itochondrial function is impaired in diabetic and obese subjects and has been suggested to be a crucial factor in the pathogenesis of insulin resistance. This impairment can be demonstrated by a reduced activity of key enzymes involved in oxidative metabolism pathways and the electron transport chain (1). Additionally, skeletal muscle mitochondria from type II diabetic and obese subjects demonstrate a reduced activity of rotenone-sensitive $\mathrm{NADH}: \mathrm{O}_{2}$ oxidoreductase, as well as a reduction in the size of the mitochondria (2). Endurance exercise can overcome these attenuations in mitochondria function 
as it improves insulin sensitivity (3) and increases fat oxidation (4). These adaptations are caused, in part, by the exercise-stimulated increase in the expression and activity of the genes and proteins regulating these processes (5-9). The regulation of metabolic genes involved in improved insulin sensitivity and increased fat oxidation is under the control of several transcriptional co-activators and transcription factors, which are also regulated by exercise and include peroxisome-proliferator-activated receptor (PPAR)- $\gamma$ co-activator-1 (PGC-1 $\alpha)(6,9-13)$, the PPAR family $(6,8,14)$, sterol regulatory element binding protein-1c (SREBP-1c) (15), and the forkhead type transcription factor, FKHR (also known as Foxo1) (16).

PGC-1 $\alpha$ is a nuclear transcriptional co-activator that regulates several important metabolic processes, including mitochondrial biogenesis, adaptive thermogenesis, respiration, insulin secretion, and gluconeogenesis (17-19). The expression of PGC-1 $\alpha$ mRNA is prominent in tissues with high-energy demands, such as heart and skeletal muscle $(18,19)$. PGC-1 $\alpha$ induces mitochondrial biogenesis by co-activating specific transcription factors, such as the nuclear respiratory factors 1 and 2a (NRF-1 and NRF-2a) (20) and the nuclear receptor estrogen-related receptor alpha $(E R R \alpha)(21,22)$. When activated, these transcription factors regulate the expression of genes involved in mitochondrial biogenesis and oxidative phosphorylation (2022). Several lines of evidence suggest that the regulation of skeletal muscle PGC-1 $\alpha$ is via AMPK and/or calcineurin signaling pathways (13, 23-26). Recently, it was shown that single leg exercise increased both the mRNA expression of myocyte-enriched calcium interacting protein (MCIP1), a marker of calcineurin activity (27), and PGC-1 $\alpha$ (25). A new member of the PGC-1 family, PGC-1-related co-activator (PRC) contains several domains homologous to PGC-1 $\alpha$, which are important for interacting with both nuclear receptors and RNA (17). Functional studies have shown that PRC directly co-activates NRF-1 and when cooperating with CBER coactivates cytochrome-c (28). PRC has functional implications similar to PGC-1 $\alpha$, and its potential coactivation of transcription factors would result in increases in genes regulating mitochondrial biogenesis and oxidative phosphorylation.

A network of target genes involved in substrate metabolism is under the control of the nuclear receptor superfamily of PPARs. The three PPAR isoforms known so far (PPAR $\alpha, \operatorname{PPAR} \beta / \delta$ and PPAR $\gamma$ ) are functionally incongruent (29). For example PPAR $\alpha$ and PPAR jointly regulate plasma lipid profiles by induction of fatty acid oxidation on the one hand (PPAR $\alpha$ ) and lipogenesis and lipid storage in liver and adipose tissue on the other (PPAR $\gamma$ ). In addition, PPAR $\gamma$ has been implicated in the regulation of whole body insulin sensitivity. Hence, PPAR $\alpha$ and $\gamma$ are targets in the treatment of hyperlipidemia and insulin resistance, both of which can also be improved, probably along the same lines, by endurance exercise. On the other hand, activation of PPAR $\beta / \delta$ induces genes involved in lipid catabolism and adaptive thermogenesis. The thermogenic role of PPAR $\beta / \delta$ closely mimics the effect of PGC- $1 \alpha(20,30)$. Given the strong association between PPAR $\beta / \delta$ and PGC- $1 \alpha$ in cultured cells and tissue (31), it is not unlikely that part of the effects of PGC- $1 \alpha$ (mitochondrial biogenesis) is mediated via PPAR $\beta / \delta$. Hence, we anticipated that exercise, a recognized stimulus of mitochondrial biogenesis, jointly induces PGC- $1 \alpha$ and PPAR $\beta / \delta$. The regulation of lipid and glucose homeostasis, via members of the PPAR family, occurs in conjunction with their heterodimeric partner, the 9-cis-retinoic acid receptor (RXR) (32, 33), as well as their allosteric interactions with FFA (34, 35). Additionally, the regulation of gene transcription by the PPAR isoforms and RXR involves, in part, ligand 
mediated interactions with PGC-1 $\alpha$ (31, 36, 37). Therefore, the responsiveness of RXR mRNA expression to endurance exercise will be examined as well.

SREBP-1c plays a crucial role in regulating genes involved in directing fatty acids towards storage (38) and has been suggested to up-regulate fatty acid synthase (FAS), acetyl-CoA carboxylase-1 (ACC-1), and stearoyl-CoA desaturase-1 (SCD-1) (15, 39). FKHR has been suggested to influence glucose oxidation by regulating glucose -6-phosphatase (40), pyruvate dehydrogenase-4 (PDK4) (41), and lipoprotein lipase (16) gene expression. However, the effect of exercise on the mRNA expression of these transcription factors is largely unknown.

Signaling molecules, including free fatty acids (FA), circulating hormones and glycogen, are known to regulate gene transcription. Fasting, a condition that rapidly increases the levels of circulating FFA's has been shown to increase the gene expression of liver PGC-1 $\alpha$ mRNA (42, 43), while it is well known that fatty acids regulate the PPAR family (35). In contrast it has been shown that FA's down-regulate SREBP activity (44). As physical exercise stimulates lipolysis and increases circulatory FFA levels, the effect of exercise, per se, on induction of metabolic transcription factors can be biased by elevated FFA levels. In an attempt to better understand the pathways involved in eliciting the adaptive response to exercise, the aim of the present study was to investigate the effect of acute endurance exercise on the mRNA regulation of the above mentioned key metabolic transcriptional co-activators and transcription factors and to delineate the effect of exercise from the effect of elevated levels of circulating FFA. To this end, exercise was performed once in the fasted state and once in the glucose-fed state.

The combined exercise and fasting-induced increase in plasma FFA levels and fat oxidation can be almost completely blunted by ingestion of carbohydrates prior to and during exercise $(45,46)$. Therefore, $2 \mathrm{~h}$ of endurance exercise was performed on two separate occasions, one in the fasted state and one with carbohydrate ingestion prior to and during the trial. We have previously used this model to distinguish between the effects of exercise and circulating FFA levels on uncoupling protein-3 expression (UCP3) $(45,46)$.

\section{MATERIALS AND METHODS}

\section{Subjects}

Seven healthy, untrained male volunteers participated in this study as previously described (46). The nature and risks of the experimental procedure were explained to the subjects, and all subjects gave their written informed consent. The study was approved by the Medical-Ethical Committee of Maastricht University.

\section{Experimental design}

Experimental design was undertaken as previously described (46). One week before the study, each subject performed an incremental exercise test on an electromagnetically braked cycle ergometer (Lode Excalibur, Groningen, The Netherlands) to determine maximal oxygen consumption $\left(\mathrm{V}_{\mathrm{O} \text { max }}\right)$. Exercise was performed until voluntary exhaustion or until the subject could no longer maintain a pedaling rate of $\geq 60 \mathrm{rpm}$. Oxygen consumption and carbon dioxide production were measured using open-circuit spirometry (Oxycon-ß Mijnhard, The Netherlands). 
Following this, two separate trials were performed using a randomized crossover design with either the water or with the glucose trial performed. These two trials were separated by 1 week. Trial 1: After an overnight fast, a percutaneous muscle biopsy was taken from the m. vastus lateralis. The muscle biopsy was immediately frozen in liquid nitrogen and stored at $-80{ }^{\circ} \mathrm{C}$ until assayed. Following this, a Teflon canula was inserted into an antecubital vein for sampling of blood. Subjects were rested on a bed and a baseline blood sample was taken (baseline, $t=-60$ ). After this, subjects ingested $1.4 \mathrm{~g} / \mathrm{kg}$ body weight of glucose (dissolved in water to a 20\% solution and flavored with $1 \mathrm{ml}$ lemon juice) and at $t=-10,30,60,90,180,240$, and $300 \mathrm{~min}$ subjects ingested $0.35 \mathrm{~g} / \mathrm{kg}$ body weight of glucose (dissolved in water to a $10 \%$ solution and flavored with $1 \mathrm{ml}$ lemon juice). After $1 \mathrm{~h}$ of rest, subjects started exercising at $50 \%$ of Wmax for $2 \mathrm{~h}(t=0)$. During exercise, blood samples were taken every $30 \mathrm{~min}$. Immediately after $2 \mathrm{~h}$ of exercise, a second muscle biopsy was taken. After this, subjects rested on a bed for $4 \mathrm{~h}$ and a third and fourth muscle biopsy was taken after 1 and $4 \mathrm{~h}$ of rest. Blood samples were taken every hour. Indirect calorimetry was performed continuously at rest and the last $10 \mathrm{~min}$ of every half hour during exercise. Trial 2: This was exactly the same as for Trial 1, however, the subjects remained fasted before, during and after the exercise bout and received water without glucose.

\section{Muscle sampling, treatment, and analysis}

Skeletal muscle samples were obtained under local anesthesia from the belly of the vastus lateralis muscle using a percutaneous needle biopsy technique (47). Total RNA was isolated using an acid phenol method (48), with an additional DNAse digestion step with concomitant acid phenol extraction and ethanol precipitation. RNA (2 $\mu \mathrm{g})$ was reverse-transcribed to cDNA using Random Hexomer primers and the Stratascript enzyme (Stratagene, The Netherlands). Real-Time PCR was performed using an MX3000p thermal cycler system and Brilliant ${ }^{\circledR}$ SYBER Green QPCR Master Mix (Stratagene, The Netherlands). The PCR conditions for all genes (for primer sequences see Table 1) consisted of one denaturing cycle at $90^{\circ} \mathrm{C}$ for $10 \mathrm{~min}$, 40 cycles consisting of denaturing at $90^{\circ} \mathrm{C}$ for $30 \mathrm{sec}$, annealing for $60 \mathrm{sec}$ at the temperature specific for each gene (Table 1) and elongation at $72^{\circ} \mathrm{C}$ for $60 \mathrm{sec}$. At the end of the PCR, the samples were subjected to a melting curve analysis. All genes were normalized against ribosomal $28 \mathrm{~S}$ mRNA.

\section{Blood analysis}

Blood was collected in tubes containing EDTA to prevent clotting and immediately centrifuged at $4000 \mathrm{rpm}$ for $10 \mathrm{~min}$ at $4^{\circ} \mathrm{C}$. Plasma was frozen in liquid nitrogen and stored at $-80^{\circ} \mathrm{C}$. Plasma substrates were determined using the hexokinase method (Roche, Basel, Switzerland) for glucose and the Wako NEFA C testkit (Wako Chemicals, Neuss, Germany) for free fatty acids.

\section{Calculations}

Oxygen consumption $\left(\mathrm{V}_{\mathrm{O} 2}\right)$ and carbon dioxide production $\left(\mathrm{V}_{\mathrm{CO} 2}\right)$ were measured using opencircuit spriometry (Oxycon- $\Omega$, Mijnhard, The Netherlands), and these values were used to calculate the respiratory exchange ratio (RER) as well as fat and carbohydrate oxidation during and after exercise in the glucose and fasted treatments. 


\section{Statistical analysis}

Two-way repeated measures ANOVA followed by pairwise multiple comparisons were performed using SPSS/PC (V12.0) to examine differences in measured parameters between the glucose and fasted treatment at the various time points, treating treatment as the between-subject factor and time as the within-subject factor. The repeated measures ANOVA was performed with and without adjusting for PGC- $1 \alpha$, i.e., treating PGC- $1 \alpha$ as a covariate. The interaction between time and treatment was also examined. For comparing overall differences between treatments, areas under the curve were calculated for $t=30$ to $t=120$ during exercise and $t=180$ to $t=360$ postexercise. Pearson correlation coefficients were calculated to determine the relationship between selected variables. All data are presented as mean \pm SEM and a $P$-value of $<0.05$ was considered statistically significant.

\section{RESULTS}

\section{Blood analysis}

Plasma free-fatty acid concentration increased during exercise in the fasted state, a response that was significantly blunted in the glucose ingestion trial at all time points $(P<0.01$; Table 2). Relative to the fasted state, blood glucose concentration increased during glucose ingestion. No difference in energy expenditure was observed between the fasting and glucose treatments.

\section{Substrate oxidation}

Respiratory exchange ratio (RER) was significantly higher $(P<0.05)$ at every time point in the glucose treatment compared to the fasted state (Table 3 ). Carbohydrate oxidation was significantly higher $(P<0.05)$, and fat oxidation was significantly lower $(P<0.05)$ at every time point in the glucose treatment compared to the fasted state (Table 3). During exercise, fat oxidation increased between $t=30$ and $t=120$ in both conditions $(P<0.001)$, but there was no time vs treatment interaction. Carbohydrate oxidation decreased between $t=30$ and $t=120$ in the glucose treatment $(P<0.05)$, whereas this decrease between $t=30$ and $t=120$ in the fasted state was almost significant (Table 3, $P=0.06$ ). In both conditions, carbohydrate and fat oxidation reached a steady state post-exercise. Area under the carbohydrate oxidation vs time curve was significantly higher in the glucose treatment compared to the fasted state, both during exercise and post-exercise $(P<0.05)$, whereas area under the fat oxidation vs time curve was lower in the glucose treatment compared to the fasted state $(P<0.05)$.

\section{The effect of FFA levels on the regulation of transcription factors}

Under resting, pre-exercise conditions with similar blood glucose and FFA levels, there was no difference in expression of the measured transcription factors between the trials. During and post-exercise, despite major differences in plasma FFA levels, we did not observe differences in gene expression between the two trials $(P>0.05)$. Therefore, the results presented below are for the fasted and the glucose trials. The values provided are the means of both trials for each subject. 


\section{PGC-1 $\alpha$ and PRC}

PGC-1 $\alpha$ mRNA was increased significantly 4.8 -fold immediately post-exercise and continued to increase by 12 -fold $1 \mathrm{~h}$ post-exercise $(P=0.002)$. By $4 \mathrm{~h}$ post-exercise PGC- $1 \alpha$, was lower than at $1 \mathrm{~h}$ post-exercise $(P<0.01)$ and had almost returned to basal levels $(P=0.065 ;$ Fig. $1 A)$. In a similar response to PGC- $1 \alpha$, PRC mRNA was significantly increased 3.3-fold immediately postexercise and remained significantly elevated 4 h post-exercise $(P=0.01$; Fig. $1 B)$. As PGC- $1 \alpha$ activation has been linked with calcineurin signaling, we also measured the mRNA expression of MCIP1, a marker of calcineurin activation. MCIP1 mRNA increased 0.85 -fold immediately postexercise $(P=0.07)$ and continued to increase significantly by 3 -fold $1 \mathrm{~h}$ post-exercise $(P=0.01)$.

\section{PPAR's and RXR}

There was no significant change in PPAR $\alpha$ mRNA ( $P=0.31$; Fig. $2 A)$, whereas PPAR $\gamma$ mRNA tended to decrease post-exercise $(P=0.06$; Fig. $2 B)$. In contrast to this, PPAR $\beta / \delta$ mRNA was significantly increased 2-fold $4 \mathrm{~h}$ post-exercise $(P=0.019$; Fig. $1 C)$. As PGC- $1 \alpha$ is also known to directly regulate gene transcription, we performed repeated measures of ANOVA for PPAR $\beta / \delta$ while adjusting for PGC- $1 \alpha$ as a covariate. This analysis revealed the same time effect as above, with PPAR $\beta / \delta$ mRNA increasing at $4 \mathrm{~h}$ post-exercise irrespective of the exercise trail performed. $\mathrm{RXR} \alpha$ mRNA expression was not altered at any time point ( $P=0.70$; Fig. $2 C)$.

\section{SREBP-1c and FKHR}

SREBP-1c mRNA did not change at any time point ( $P>0.05$; Fig. $2 D)$, while FKHR mRNA increased by 1.5 and 2-fold, 1 and $4 \mathrm{~h}$ post-exercise, respectively $(P<0.05$; Fig. $1 D)$.

\section{DISCUSSION}

In the present study, we aimed to investigate whether the effect of acute endurance exercise on the regulation of several metabolic transcriptional co-activators and transcription factors is a direct effect of exercise or an effect of elevated levels of circulating FFA. Our results demonstrate that the increase in mRNA expression of the transcriptional co-activators PGC- $1 \alpha$ and PRC, during acute endurance exercise, is an effect of signals inherent to the contracting skeletal muscles. A similar response was observed for the mRNA of several transcription factors, including PPAR $\beta / \delta$ and FKHR, which were induced 1-4 h post-exercise, suggesting that their regulation was linked to factors, not inherent but associated with, muscle contraction, that are presently unknown. We show, however, that the induction of these metabolic transcription factors is independent of circulatory FFA levels, even if in the millimolar range.

We observed that after $2 \mathrm{~h}$ of acute endurance cycling exercise that PGC-1 $\alpha$ mRNA was increased 4.8-fold, continued to increase by 12 -fold during the first hour post-exercise and remained elevated compared to pre-exercise values, but returned to values immediately postexercise. It has been observed in humans performing two-legged knee extensor exercise for $3 \mathrm{~h}$ at $50 \%$ of $V \mathrm{O}_{2 \max }$, that PGC-1 $\alpha$ mRNA does not increase immediately after exercise but at $2 \mathrm{~h}$ post exercise ( 10-fold) and returning to basal levels when measured $24 \mathrm{~h}$ post-exercise (12). In contrast, increases in PGC-1 $\alpha$ mRNA were not observed in humans after $1 \mathrm{~h}$ of acute endurance 
cycling exercise at an intensity corresponding to $63 \%$ of $\mathrm{VO}_{2 \max }$ (8). It is therefore possible that PGC-1 $\alpha$ mRNA requires a stimulus from muscle contraction lasting more than $1 \mathrm{~h}$ before an increase in mRNA can be observed. Additionally, the intensity and mode of the exercise bout may play a role in the regulation of PGC- $1 \alpha$ mRNA. Although PGC- $1 \alpha$ mRNA returned to basal levels after $4 \mathrm{~h}$ of recovery, we have previously observed a significant increase in PGC-1 $\alpha$ mRNA after 8 weeks of endurance training (60-80\% of $\left.V \mathrm{O}_{2 \max }\right)$, which demonstrates that the accumulative effect of many consecutive acute endurance exercise bouts increases PGC-1 $\alpha$ mRNA levels (6) and hence is likely to contribute to increased mitochondrial biogenesis. Differences in the acute and chronic responses of PGC-1 $\alpha$ mRNA is most likely due to the acute and chronic changes in cellular homeostasis with the constant stress of exercise training stimulating a gradual increase in PGC- $1 \alpha$ gene expression. As PGC- $1 \alpha$ is a potent activator of mitochondrial biogenesis, our results suggest that the exercise induced signals, which stimulate skeletal muscle mitochondrial biogenesis come directly from the contracting skeletal muscle and are independent of signals stimulated from changes in circulating FFA's. Calcineurin signaling has been suggested as one of the factors regulating PGC-1 $\alpha$ (23). We observed that MCIP1 mRNA, a marker of calcineurin activation, increased in a similar manner to PGC- $1 \alpha$. This finding supports the increase in MCIP1 and PGC-1 $\alpha$ mRNA recently observed in human skeletal muscle after $45 \mathrm{~min}$ of single leg exercise (25). Although indirect, these findings support the suggested role of calcineurin in the regulation of PGC- $1 \alpha$.

In addition to the increase in PGC- $1 \alpha$ we observed for the first time that acute endurance exercise increases the gene expression of PGC-1-related co-activator (PRC), a gene functionally related to PGC-1 $\alpha$ (28). Like PGC-1 $\alpha$, the regulation of PRC mRNA increased immediately post-exercise and remained elevated at $4 \mathrm{~h}$ post-exercise, however, there appeared to be a tendency for PRC mRNA to start to decrease during the recovery period and it is most likely that it would be similar to basal levels $24 \mathrm{~h}$ post-exercise. PRC, like PGC-1 $\alpha$, increases NRF-1dependent transcription of several promoters, most likely through its direct interaction with the DNA binding domain of NRF-1 (28). Although the exact functional role of PRC is not known, it appears to be a growth-regulated coactivator responsible, in part, for activating transcription factors required for cell growth (49). Contraction-related signals may drive PGC-1 $\alpha$ and PRC gene expression as both were increased immediately and $1 \mathrm{~h}$ post-exercise, independently of the levels of circulating FFA. The concordant down-regulation in type 2 diabetes of discrete gene sets involved in oxidative phosphorylation (OXPHOS) who are all under the control of PGC-1 $\alpha$ indicate that mitochondrial biogenesis, either via physical exercise or via pharmalogical intervention, can be a target to combat diabetes. This is supported by our previous observations that 8 weeks of endurance exercise training up-regulated PGC- $1 \alpha$ mRNA and protein as well as the mRNA several OXPHOS genes, including COX4, GLUT4, and CPT1 (6).

The PPAR family of transcription factors is a potent regulator of genes involved in lipid metabolism. In the present study we did not observe any changes in skeletal muscle PPAR $\alpha$ mRNA, which is in support of others (28). Even though an increase in PPAR $\alpha$ mRNA was not observed, the increase in PGC-1 $\alpha$ may have had downstream effects thereby activating PPAR $\alpha$. It appears that the regulation of PPAR $\alpha$ may require at least several acute exercise bouts as PPAR $\alpha$ mRNA and protein has been observed to increase with 8-12 weeks of endurance training performed between $60-80 \%$ of $\operatorname{VO}_{2 \max }(14,50)$. However, we did observe an increase in 
PPAR $\beta / \delta$ mRNA 4 h post-exercise and a tendency for PPAR $\gamma$ to decrease immediately postexercise. As PGC-1 $\alpha$ mRNA was also increased by exercise and is known to regulate PPAR gene expression, it was possible that the increase in PPAR $\beta / \delta$ mRNA was not a response to exercise but in fact a response to PGC- $1 \alpha$. After performing the repeated measures ANOVA again with the effect of PGC- $1 \alpha$ adjusted, PPAR $\beta / \delta$ mRNA was still increased $4 \mathrm{~h}$ post-exercise, irrespective of the exercise trial. Therefore, in the present study, the increase in PPAR $\beta / \delta \mathrm{mRNA}$ is an effect of exercise and not due to transcriptional regulation by PGC- $1 \alpha$. This is the first time PPAR $\beta / \delta$ mRNA has been measured in human skeletal muscle after an acute bout of endurance exercise. Results from one of our previous studies show that PPAR $\beta / \delta$ mRNA is not increased following 8 weeks of endurance training, with the final measurement taken approximately $48 \mathrm{~h}$ after the last exercise bout (6). In cultures of primary human muscle cells and rat L6 myotubes, (51) as well as in mouse white adipose tissue (31), the activation of PPAR $\beta / \delta$ increases fatty acid oxidation and induces the expression of lipid regulatory genes. Therefore, the increase in $\mathrm{PPAR} \beta / \delta$ mRNA with acute exercise may be a mechanism, which improves skeletal muscle fatty acid oxidation capacity, a common adaptation to endurance exercise. PPAR $\gamma$ mRNA tended to be reduced immediately post-exercise and appeared to be returning to basal levels after $4 \mathrm{~h}$ of recovery. In part, this result is in contrast to that of Tunstall et al. (8) who observed no change in PPAR $\gamma$ mRNA immediately after $1 \mathrm{~h}$ of exercise, however, they did observe a sustained decrease in PPAR $\gamma$ mRNA after 3 weeks of endurance training. As mentioned previously, an exercise intensity greater than 50 and $63 \%$ of $V_{2}$ max used in the present study and by Tunstall et al. (8) may be required to elicit changes in gene transcription of PPAR $\beta / \delta$ and PPAR $\gamma$.

RXR is an important regulator of genes involved in fatty acid metabolism as it acts as a heterodimeric partner with members of the PPAR subfamily (32). After binding to their ligand, the transcriptional activity of these receptors is enhanced by the release of co-repressors and the recruitment of co-activators, such as PGC- $1 \alpha$ (30). For the first time we have measured RXR mRNA after acute exercise and did not observe any transcriptional regulation. It is possible that the basal level of RXR in the subjects participating in the present study may have been in sufficient abundance to maintain skeletal muscle homeostasis, when placed under metabolic stress caused by acute endurance exercise performed at $50 \%$ of $V_{2} O_{2 \max }$. Further studies are required to see if RXR mRNA is regulated when exercise is performed at greater intensities.

SREBP-1c is a helix-loop-helix transcription factor, which is implicated in lipid metabolism through its regulation of fatty acid synthase (FAS), acetyl-CoA carboxylase-1 (ACC-1), and stearoyl-CoA desaturase-1 (SCD-1) $(15,39)$. In the present study, SREBP-1c mRNA was not significantly altered after acute endurance exercise, which supports previous observations in humans (8). In mice it has previously been observed that SREBP-1c mRNA is not changed after $1 \mathrm{~h}$ of treadmill running, but is increased 2.0-fold when measured $12 \mathrm{~h}$ after a $6 \mathrm{~h}$ bout of treadmill running (15). It is possible that to stimulate changes in human SREBP-1c mRNA a longer duration of exercise may be required or that the sampling time should be extended to beyond $4 \mathrm{~h}$ post-exercise. The study by Ikeda et al. (15) also observed a 2.0-fold increase in SREBP-1c mRNA after 2 weeks of swimming training. This is again in contrast to the observations by Tunstall et al (8) who did not observe any changes in human SREBP-1c mRNA measured $3 \mathrm{~h}$ after the last bout of a 9-day endurance training program. These discrepancies between human and rodent studies may lie in the duration of the acute exercise bouts, the duration and intensities of the training programs, or the sampling time post-exercise. 
We have also observed, for the first time in humans, an increase in the FKHR mRNA 1 and 4-hrs after an acute endurance exercise bout. This supports a recent observation in mice following $6 \mathrm{~h}$ of treadmill running (16). FKHR is a member of the forkhead family of transcription factors (52) and can act as a cofactor of nuclear hormone receptors (53) and as a part of a nuclear cofactor complex containing CBR/p300 (54), which is critical for, among others, the nuclear receptor signaling of PPAR's $(55,56)$. The LPL gene promoter contains both PPAR and some glucocorticoid response elements $(57,58)$. It has been demonstrated that ectopic gene expression of FKHR in C2C12 cells enhanced LPL gene expression, while the addition of the PPAR $\alpha$ agonist Wy14643 further enhanced its expression (16). This suggests that FKHR, in combination with PPAR $\alpha$, can increase LPL gene expression. In the liver, FKHR activates the gene expression of the key gluconeogenesis enzyme, G6Pase (40). Interestingly, both G6Pase and FKHR mRNA's are induced by glucocorticoid (59), which are elevated after exercise (60). Therefore, the exercise-induced increase in skeletal muscle FKHR may increase fatty acid oxidation by increasing LPL activity. It is possible that exercise may also increase gluconeogenesis, via the glucocorticoid stimulation of liver FKHR and consequently G6Pase activity.

Although our results show that the regulation of the transcriptional co-activators and transcription factors are independent of circulating FFA's, it is possible that the exercise-induced regulation may also be via hormone signaling, such as glucocorticoids, which are known to increase during exercise. Glucose and glycogen are also known signaling molecules and regulators of gene transcription, however, it is doubtful that they would have played a significant role in this model. Plasma glucose concentrations did not increase during the fasting or the glucose trials, respectively, and were not different before or immediately after exercise when comparing the fasting with the glucose trial. Furthermore, it has previously been shown that the type of exercise trials used in the present study do not result in a difference in muscle glycogen oxidation (61). It is also important to note that in the present study we used a very low exercise intensity corresponded to $50 \%$ of maximal power output. It cannot be ruled out that a higher exercise intensity, performed over a similar duration of $2 \mathrm{~h}$, may result in increases in some of the transcription factors that have not increased in this study. However, it has been shown that low-intensity endurance training does increase fat oxidation and leads to marked changes in genes encoding key enzymes in fat metabolism, such as acetyl-CoA carboxylase-2 and lipoprotein lipase (7). Therefore, low-intensity exercise does provide stress signals that result in changes in gene expression required to maintain cellular homeostasis. However, transcription of target genes is not necessarily dependent upon increases in the gene transcription of their transcription factors.

In summary, we have demonstrated that the gene regulation of skeletal muscle metabolic transcriptional co-activators PGC- $1 \alpha$ and PRC and transcription factors PPAR $\beta / \delta$ and FKHR, during acute endurance exercise, are independent of the levels of circulating FFA. The regulation of these genes is mostly likely an effect of inherent signals, (PGC-1 $\alpha$, PRC) or associated signals (PPAR $\beta / \delta$, FKHR) stimulated from the contracting skeletal muscle. Among others, our observation of an increase in MCIP1 mRNA suggests that calcineurin signaling may be an important factor in the exercise-induced regulation of PGC- $1 \alpha$. Additionally, we cannot rule out the possible effects of circulating hormones such, glucocorticoids, on the regulation of the mRNA's measured in the present study. Remarkably, these exercise-responsive genes have been 
implicated in mitochondrial biogenesis and or substrate oxidation. Therefore, endurance exercise may be able to overcome the mitochondrial and oxidative impairments observed in diabetic subjects. The mRNA levels of transcription factors, related more to lipogenesis such as (PPAR $\gamma$ and SREBP-1c), or to hepatic rather than skeletal muscle fat oxidation such as (PPAR $\alpha$ ), remained unaffected by both exercise and/or increases in FFA levels. The exact mechanisms contributing to the exercise-induced changes in the mRNA of these transcriptional co-activators and transcription factors are presently unknown and further studies are required to determine which signalling pathways are responsible for these changes.

\section{REFERENCES}

1. Simoneau, J. A., Veerkamp, J. H., Turcotte, L. P., and Kelley, D. E. (1999) Markers of capacity to utilize fatty acids in human skeletal muscle: relation to insulin resistance and obesity and effects of weight loss. FASEB J. 13, 2051-2060

2. Kelley, D. E., He, J., Menshikova, E. V., and Ritov, V. B. (2002) Dysfunction of mitochondria in human skeletal muscle in type 2 diabetes. Diabetes 51, 2944-2950

3. Dela, F., Mikines, K. J., von Linstow, M., Secher, N. H., and Galbo, H. (1992) Effect of training on insulin-mediated glucose uptake in human muscle. Am. J. Physiol. 263, E1134E1143

4. Holloszy, J. O., and Coyle, E. F. (1984) Adaptations of skeletal muscle to endurance exercise and their metabolic consequences. J. Appl. Physiol. 56, 831-838

5. Dela, F., Ploug, T., Handberg, A., Petersen, L. N., Larsen, J. J., Mikines, K. J., and Galbo, H. (1994) Physical training increases muscle GLUT4 protein and mRNA in patients with NIDDM. Diabetes 43, 862-865

6. Russell, A. P., Feilchenfeldt, J., Schreiber, S., Praz, M., Crettenand, A., Gobelet, C., Meier, C. A., Bell, D. R., Kralli, A., Giacobino, J. P., et al. (2003) Endurance training in humans leads to fiber type-specific increases in levels of peroxisome proliferator-activated receptorgamma coactivator-1 and peroxisome proliferator-activated receptor-alpha in skeletal muscle. Diabetes 52, 2874-2881

7. Schrauwen, P., van Aggel-Leijssen, D. P., Hul, G., Wagenmakers, A. J., Vidal, H., Saris, W. H., and van Baak, M. A. (2002) The effect of a 3-month low-intensity endurance training program on fat oxidation and acetyl-CoA carboxylase-2 expression. Diabetes 51, 22202226

8. Tunstall, R. J., Mehan, K. A., Wadley, G. D., Collier, G. R., Bonen, A., Hargreaves, M., and Cameron-Smith, D. (2002) Exercise training increases lipid metabolism gene expression in human skeletal muscle. Am. J. Physiol. Endocrinol. Metab. 283, E66-E72

9. Short, K. R., Vittone, J. L., Bigelow, M. L., Proctor, D. N., Rizza, R. A., Coenen-Schimke, J. M., and Nair, K. S. (2003) Impact of aerobic exercise training on age-related changes in insulin sensitivity and muscle oxidative capacity. Diabetes 52, 1888-1896 
10. Goto, M., Terada, S., Kato, M., Katoh, M., Yokozeki, T., Tabata, I., and Shimokawa, T. (2000) cDNA Cloning and mRNA analysis of PGC-1 in epitrochlearis muscle in swimmingexercised rats. Biochem. Biophys. Res. Commun. 274, 350-354

11. Baar, K., Wende, A. R., Jones, T. E., Marison, M., Nolte, L. A., Chen, M., Kelly, D. P., and Holloszy, J. O. (2002) Adaptations of skeletal muscle to exercise: rapid increase in the transcriptional coactivator PGC-1. FASEB J. 16, 1879-1886

12. Pilegaard, H., Saltin, B., and Neufer, P. D. (2003) Exercise induces transient transcriptional activation of the PGC-1alpha gene in human skeletal muscle. J. Physiol. 546, 851-858

13. Terada, S., Goto, M., Kato, M., Kawanaka, K., Shimokawa, T., and Tabata, I. (2002) Effects of low-intensity prolonged exercise on PGC-1 mRNA expression in rat epitrochlearis muscle. Biochem. Biophys. Res. Commun. 296, 350-354

14. Horowitz, J. F., Leone, T. C., Feng, W., Kelly, D. P., and Klein, S. (2000) Effect of endurance training on lipid metabolism in women: a potential role for PPARalpha in the metabolic response to training. Am. J. Physiol. Endocrinol. Metab. 279, E348-E355

15. Ikeda, S., Miyazaki, H., Nakatani, T., Kai, Y., Kamei, Y., Miura, S., Tsuboyama-Kasaoka, N., and Ezaki, O. (2002) Up-regulation of SREBP-1c and lipogenic genes in skeletal muscles after exercise training. Biochem. Biophys. Res. Commun. 296, 395-400

16. Kamei, Y., Mizukami, J., Miura, S., Suzuki, M., Takahashi, N., Kawada, T., Taniguchi, T., and Ezaki, O. (2003) A forkhead transcription factor FKHR up-regulates lipoprotein lipase expression in skeletal muscle. FEBS Lett. 536, 232-236

17. Kelly, D. P., and Scarpulla, R. C. (2004) Transcriptional regulatory circuits controlling mitochondrial biogenesis and function. Genes Dev. 18, 357-368

18. Puigserver, P., and Spiegelman, B. M. (2003) Peroxisome proliferator-activated receptorgamma coactivator 1 alpha (PGC-1 alpha): transcriptional coactivator and metabolic regulator. Endocr. Rev. 24, 78-90

19. Knutti, D., and Kralli, A. (2001) PGC-1, a versatile coactivator. Trends Endocrinol. Metab. 12, 360-365

20. Wu, Z., Puigserver, P., Andersson, U., Zhang, C., Adelmant, G., Mootha, V., Troy, A., Cinti, S., Lowell, B., Scarpulla, R. C., and Spiegelman, B. M. (1999) Mechanisms controlling mitochondrial biogenesis and respiration through the thermogenic coactivator PGC-1. Cell 98, 115-124

21. Mootha, V. K., Handschin, C., Arlow, D., Xie, X., St Pierre, J., Sihag, S., Yang, W., Altshuler, D., Puigserver, P., Patterson, N., et al. (2004) Erralpha and Gabpa/b specify PGC1alpha-dependent oxidative phosphorylation gene expression that is altered in diabetic muscle. Proc. Natl. Acad. Sci. USA 101, 6570-6575 
22. Schreiber, S. N., Emter, R., Hock, M. B., Knutti, D., Cardenas, J., Podvinec, M., Oakeley, E. J., and Kralli, A. (2004) The estrogen-related receptor alpha (ERRalpha) functions in PPARgamma coactivator 1alpha (PGC-1alpha)-induced mitochondrial biogenesis. Proc. Natl. Acad. Sci. USA 101, 6472-6477

23. Lin, J., Wu, H., Tarr, P. T., Zhang, C. Y., Wu, Z., Boss, O., Michael, L. F., Puigserver, P., Isotani, E., Olson, E. N., et al. (2002) Transcriptional co-activator PGC-1 alpha drives the formation of slow-twitch muscle fibres. Nature 418, 797-801

24. Ojuka, E. O., Jones, T. E., Han, D. H., Chen, M., and Holloszy, J. O. (2003) Raising Ca2+ in L6 myotubes mimics effects of exercise on mitochondrial biogenesis in muscle. FASEB J. 17, 675-681

25. Norrbom, J., Sundberg, C. J., Ameln, H., Kraus, W. E., Jansson, E., and Gustafsson, T. (2004) PGC-1alpha mRNA expression is influenced by metabolic perturbation in exercising human skeletal muscle. J. Appl. Physiol. 96, 189-194

26. Wu, H., Kanatous, S. B., Thurmond, F. A., Gallardo, T., Isotani, E., Bassel-Duby, R., and Williams, R. S. (2002) Regulation of mitochondrial biogenesis in skeletal muscle by CaMK. Science 296, 349-352

27. Yang, J., Rothermel, B., Vega, R. B., Frey, N., McKinsey, T. A., Olson, E. N., Bassel-Duby, R., and Williams, R. S. (2000) Independent signals control expression of the calcineurin inhibitory proteins MCIP1 and MCIP2 in striated muscles. Circ. Res. 87, E61-E68

28. Andersson, U., and Scarpulla, R. C. (2001) Pgc-1-related coactivator, a novel, seruminducible coactivator of nuclear respiratory factor 1-dependent transcription in mammalian cells. Mol. Cell. Biol. 21, 3738-3749

29. Evans, R. M., Barish, G. D., and Wang, Y. X. (2004) PPARs and the complex journey to obesity. Nat. Med. 10, 355-361

30. Puigserver, P., Wu, Z., Park, C. W., Graves, R., Wright, M., and Spiegelman, B. M. (1998) A cold-inducible coactivator of nuclear receptors linked to adaptive thermogenesis. Cell 92, 829-839

31. Wang, Y. X., Lee, C. H., Tiep, S., Yu, R. T., Ham, J., Kang, H., and Evans, R. M. (2003) Peroxisome-Proliferator-Activated Receptor delta Activates Fat Metabolism to Prevent Obesity. Cell 113, 159-170

32. Auwerx, J. (1999) PPARgamma, the ultimate thrifty gene. Diabetologia 42, 1033-1049

33. Kersten, S., Desvergne, B., and Wahli, W. (2000) Roles of PPARs in health and disease. Nature 405, 421-424

34. Kliewer, S. A., and Willson, T. M. (1998) The nuclear receptor PPARgamma - bigger than fat. Curr. Opin. Genet. Dev. 8, 576-581 
35. Kliewer, S. A., Sundseth, S. S., Jones, S. A., Brown, P. J., Wisely, G. B., Koble, C. S., Devchand, P., Wahli, W., Willson, T. M., Lenhard, J. M., et al. (1997) Fatty acids and eicosanoids regulate gene expression through direct interactions with peroxisome proliferator-activated receptors alpha and gamma. Proc. Natl. Acad. Sci. USA 94, 43184323

36. Delerive, P., Wu, Y., Burris, T. P., Chin, W. W., and Suen, C. S. (2002) PGC-1 functions as a transcriptional coactivator for the retinoid X receptors. J. Biol. Chem. 277, 3913-3917

37. Vega, R. B., Huss, J. M., and Kelly, D. P. (2000) The coactivator PGC-1 cooperates with peroxisome proliferator-activated receptor alpha in transcriptional control of nuclear genes encoding mitochondrial fatty acid oxidation enzymes. Mol. Cell. Biol. 20, 1868-1876

38. Brown, M. S., and Goldstein, J. L. (1997) The SREBP pathway: regulation of cholesterol metabolism by proteolysis of a membrane-bound transcription factor. Cell 89, 331-340

39. Latasa, M. J., Moon, Y. S., Kim, K. H., and Sul, H. S. (2000) Nutritional regulation of the fatty acid synthase promoter in vivo: sterol regulatory element binding protein functions through an upstream region containing a sterol regulatory element. Proc. Natl. Acad. Sci. USA 97, 10619-10624

40. Schmoll, D., Walker, K. S., Alessi, D. R., Grempler, R., Burchell, A., Guo, S., Walther, R., and Unterman, T. G. (2000) Regulation of glucose-6-phosphatase gene expression by protein kinase Balpha and the forkhead transcription factor FKHR. Evidence for insulin response unit-dependent and -independent effects of insulin on promoter activity. J. Biol. Chem. 275, 36324-36333

41. Furuyama, T., Kitayama, K., Yamashita, H., and Mori, N. (2003) Forkhead transcription factor FOXO1 (FKHR)-dependent induction of PDK4 gene expression in skeletal muscle during energy deprivation. Biochem. J. 375, 365-371

42. Herzig, S., Hedrick, S., Morantte, I., Koo, S. H., Galimi, F., and Montminy, M. (2003) CREB controls hepatic lipid metabolism through nuclear hormone receptor PPAR-gamma. Nature 426, 190-193

43. Rhee, J., Inoue, Y., Yoon, J. C., Puigserver, P., Fan, M., Gonzalez, F. J., and Spiegelman, B. M. (2003) Regulation of hepatic fasting response by PPARgamma coactivator-1alpha (PGC1): requirement for hepatocyte nuclear factor 4alpha in gluconeogenesis. Proc. Natl. Acad. Sci. USA 100, 4012-4017

44. Matsuzaka, T., Shimano, H., Yahagi, N., Amemiya-Kudo, M., Yoshikawa, T., Hasty, A. H., Tamura, Y., Osuga, J., Okazaki, H., Iizuka, Y., et al. (2002) Dual regulation of mouse Delta(5)- and Delta(6)-desaturase gene expression by SREBP-1 and PPARalpha. J. Lipid Res. 43, 107-114

45. Coyle, E. F., Jeukendrup, A. E., Wagenmakers, A. J., and Saris, W. H. (1997) Fatty acid oxidation is directly regulated by carbohydrate metabolism during exercise. Am. J. Physiol. 273, E268-E275 
46. Schrauwen, P., Hesselink, M. K., Vaartjes, I., Kornips, E., Saris, W. H., Giacobino, J. P., and Russell, A. (2002) Effect of acute exercise on uncoupling protein 3 is a fat metabolismmediated effect. Am. J. Physiol. Endocrinol. Metab. 282, E11-E17

47. Bergstrom, J. (1975) Percutaneous needle biopsy of skeletal muscle in physiological and clinical research. Scand. J. Clin. Lab. Invest. 35, 609-616

48. Chomczynski, P., and Sacchi, N. (1987) Single-step method of RNA isolation by acid guanidinium thiocyanate- phenol-chloroform extraction. Anal. Biochem. 162, 156-159

49. Scarpulla, R. C. (2002) Transcriptional activators and coactivators in the nuclear control of mitochondrial function in mammalian cells. Gene 286, 81-89

50. Russell, A., Wadley, G., Hesselink, M. K., Schaart, G., Léger, B., Garnham, A., Kornips, E., Cameron-Smith, D., Muzzin, P., Snow, R., et al. (2003) UCP3 protein expression is lower in type I, IIa and IIx muscle fiber types of endurance trained compared to untrained subjects. Pflugers Arch. 445, 563-569

51. Muoio, D. M., MacLean, P. S., Lang, D. B., Li, S., Houmard, J. A., Way, J. M., Winegar, D. A., Corton, J. C., Dohm, G. L., and Kraus, W. E. (2002) Fatty acid homeostasis and induction of lipid regulatory genes in skeletal muscles of peroxisome proliferator-activated receptor (PPAR) alpha knock-out mice. Evidence for compensatory regulation by PPAR delta. J. Biol. Chem. 277, 26089-26097

52. Kaestner, K. H., Knochel, W., and Martinez, D. E. (2000) Unified nomenclature for the winged helix/forkhead transcription factors. Genes Dev. 14, 142-146

53. Schuur, E. R., Loktev, A. V., Sharma, M., Sun, Z., Roth, R. A., and Weigel, R. J. (2001) Ligand-dependent interaction of estrogen receptor-alpha with members of the forkhead transcription factor family. J. Biol. Chem. 276, 33554-33560

54. Nasrin, N., Ogg, S., Cahill, C. M., Biggs, W., Nui, S., Dore, J., Calvo, D., Shi, Y., Ruvkun, G., and Alexander-Bridges, M. C. (2000) DAF-16 recruits the CREB-binding protein coactivator complex to the insulin-like growth factor binding protein 1 promoter in HepG2 cells. Proc. Natl. Acad. Sci. USA 97, 10412-10417

55. Kamei, Y., Xu, L., Heinzel, T., Torchia, J., Kurokawa, R., Gloss, B., Lin, S. C., Heyman, R. A., Rose, D. W., Glass, C. K., et al. (1996) A CBP integrator complex mediates transcriptional activation and AP-1 inhibition by nuclear receptors. Cell 85, 403-414

56. Rosenfeld, M. G., and Glass, C. K. (2001) Coregulator codes of transcriptional regulation by nuclear receptors. J. Biol. Chem. 276, 36865-36868

57. Bey, L., Etienne, J., Tse, C., Brault, D., Noe, L., Raisonnier, A., Arnault, F., Hamilton, M. T., and Galibert, F. (1998) Cloning, sequencing and structural analysis of 976 base pairs of the promoter sequence for the rat lipoprotein lipase gene. Comparison with the mouse and human sequences. Gene 209, 31-38 
58. Schoonjans, K., Peinado-Onsurbe, J., Lefebvre, A. M., Heyman, R. A., Briggs, M., Deeb, S., Staels, B., and Auwerx, J. (1996) PPARalpha and PPARgamma activators direct a distinct tissue-specific transcriptional response via a PPRE in the lipoprotein lipase gene. EMBO J. 15, 5336-5348

59. Barthel, A., Schmoll, D., Kruger, K. D., Roth, R. A., and Joost, H. G. (2002) Regulation of the forkhead transcription factor FKHR (FOXO1a) by glucose starvation and AICAR, an activator of AMP-activated protein kinase. Endocrinology 143, 3183-3186

60. Tharp, G. D. (1975) The role of glucocorticoids in exercise. Med. Sci. Sports 7, 6-11

61. Jeukendrup, A. E., Raben, A., Gijsen, A., Stegen, J. H., Brouns, F., Saris, W. H., and Wagenmakers, A. J. (1999) Glucose kinetics during prolonged exercise in highly trained human subjects: effect of glucose ingestion. J. Physiol. 515, 579-589

Received September 19, 2004; accepted February 11, 2005. 
Table 1

Primer sequences and annealing temperatures

\begin{tabular}{lllc}
\hline Gene & \multicolumn{1}{c}{ Forward 5' $\mathbf{- 3}^{\prime}$} & \multicolumn{1}{c}{ Reverse $\mathbf{5}^{\prime} \mathbf{- 3}^{\prime}$} & Temp \\
\hline PGC-1 $\alpha$ & GGT CTC TCC TTG CAG CAC AAG & CTG GGA TGA CCG AAG TGC TT & 60 \\
PRC & GCT GAA ACA GAG GTT CTC CG & AAA GTC TTC CCG GTT GGA CT & 60 \\
PPAR $\alpha$ & AGC TTT GGC TTT ACG GAA TAC CA & CCA CAG GAT AAG TCA CCG AGG A & 60 \\
PPAR $\beta / \delta$ & ATG GAG CAG CCA CAG GAG GAA GCC & GCA TGA GGC CCC GTC ACA GC & 58 \\
PPAR $\gamma$ & GAC CAC TCC CAC TCC TTT & CGA CAT TCA ATT GCC ATG AG & 62 \\
RXR $\alpha$ & TTC TCC ACC CAG GTG AAC TC & GAG CTG ATG ACC GAG AAA GG & 60 \\
SREBP-1c & GCA GGG GTA GGG CCA ACG GCC T & CAT GTC TTC GAA AGT GCA ATC C & 60 \\
FKHD & AAG AGC GTG CCC TAC TTC AA & CTG TTG TTG TCC ATG GAT GC & 60 \\
MCIP1 & GGC CAA ATT TGA GTC CCT CT & AGC CAG GTG TGA GCT TCC TA & 60 \\
$28 \mathrm{~s}$ & TTG AAA ATC CGG GGG AGA G & ACA TTC TTC CAA CAT GCC AG & \\
\hline
\end{tabular}




\section{Table 2}

Plasma FFA and blood glucose concentrations before, after and 1 and 4 hrs after the fasting trial and the glucose trail.

Plasma FFA ( $\mu \mathrm{mol} / \mathrm{l})$

\section{Blood Glucose (mmol/l)}

Fasting trial Glucose trial $\quad$ Fasting trial Glucose trial

\begin{tabular}{|c|c|c|c|c|}
\hline Pre & $299 \pm 54$ & $319 \pm 120$ & $5.1 \pm 0.7$ & $4.8 \pm 0.6$ \\
\hline Pst & $1042 \pm 263 *$ & $392 \pm 181$ & $4.7 \pm 0.3$ & $5.0 \pm 0.6$ \\
\hline $1 \mathrm{hr}$ & $986 \pm 215 *$ & $178 \pm 84$ & $4.1 \pm 0.3 *$ & $5.6 \pm 0.5$ \\
\hline $4 \mathrm{hr}$ & $908 \pm 175 *$ & $121 \pm 44$ & $4.3 \pm 0.5 *$ & $5.5 \pm 0.7$ \\
\hline
\end{tabular}

*, different from the same time point in the glucose trial $(P<0.01)$. 
Table 3

RER and fat and carbohydrate oxidation during and after exercise in the glucose and fasted treatments

Glucose Trial

\begin{tabular}{lccccccc}
\hline & Time & RER & $\begin{array}{c}\text { Fat } \\
\text { oxidation } \\
\mathbf{m g} / \mathbf{m i n}\end{array}$ & $\begin{array}{c}\text { CHO } \\
\text { oxidation } \\
\mathbf{m g} / \mathbf{m i n}\end{array}$ & $\mathbf{R E R}$ & $\begin{array}{c}\text { Fat } \\
\text { oxidation } \\
\mathbf{m g} / \mathbf{m i n}\end{array}$ & $\begin{array}{c}\text { CHO } \\
\text { oxidation } \\
\mathbf{m g} / \mathbf{m i n}\end{array}$ \\
\hline Exercise & 0 & $0.83 \pm 0.04$ & $88 \pm 24$ & $159 \pm 58 *$ & $0.81 \pm 0.02$ & $87 \pm 9$ & $107 \pm 26$ \\
& 30 & $0.87 \pm 0.01 *$ & $459 \pm 41 *$ & $1,478 \pm 46 *$ & $0.83 \pm 0.01$ & $617 \pm 41$ & $1,081 \pm 96$ \\
& 60 & $0.86 \pm 0.01 *$ & $529 \pm 49 *$ & $1,353 \pm 546 *$ & $0.82 \pm 0.02$ & $682 \pm 38$ & $1,007 \pm 113$ \\
& 120 & $0.84 \pm 0.01 *$ & $607 \pm 67 *$ & $1,242 \pm 104 *$ & $0.80 \pm 0.01$ & $732 \pm 55$ & $828 \pm 85$ \\
Post & 180 & $0.91 \pm 0.01 *$ & $45 \pm 9 *$ & $241 \pm 13 *$ & $0.78 \pm 0.01$ & $110 \pm 6$ & $79 \pm 15$ \\
& 240 & $0.89 \pm 0.01 *$ & $54 \pm 8 *$ & $207 \pm 13 *$ & $0.78 \pm 0.01$ & $112 \pm 7$ & $79 \pm 8$ \\
& 300 & $0.89 \pm 0.02 *$ & $52 \pm 8 *$ & $203 \pm 21 *$ & $0.76 \pm 0.01$ & $119 \pm 6$ & $52 \pm 9$ \\
& 360 & $0.9 \pm 0.01 *$ & $48 \pm 4 *$ & $221 \pm 16 *$ & $0.79 \pm 0.01$ & $101 \pm 6$ & $92 \pm 7$
\end{tabular}

Data are means \pm SE. RER, respiratory exchange ratio; CHO, carbohydrate; ${ }^{*} P<0.05$, compared with fasted treatment. 
Fig. 1

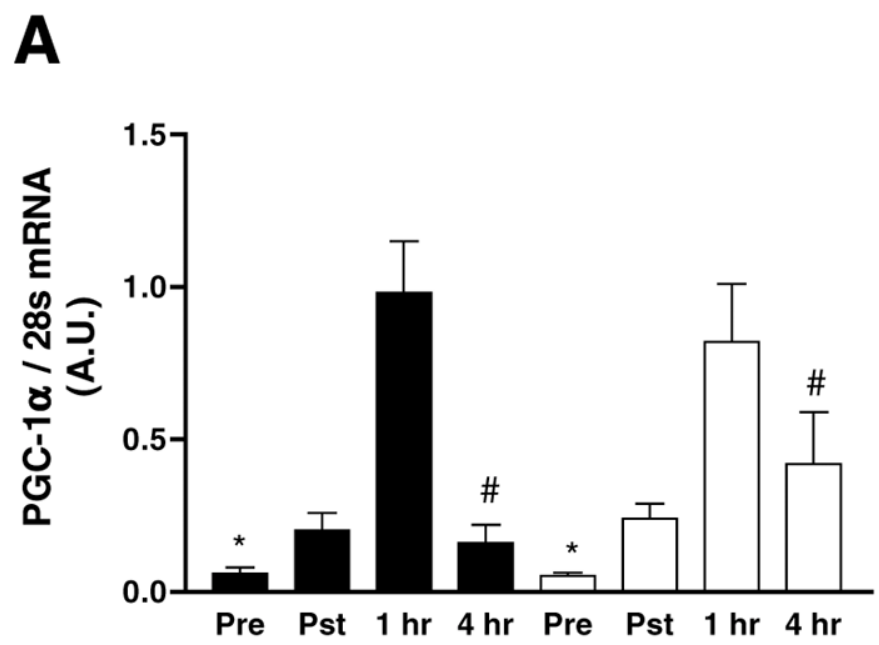

B

C
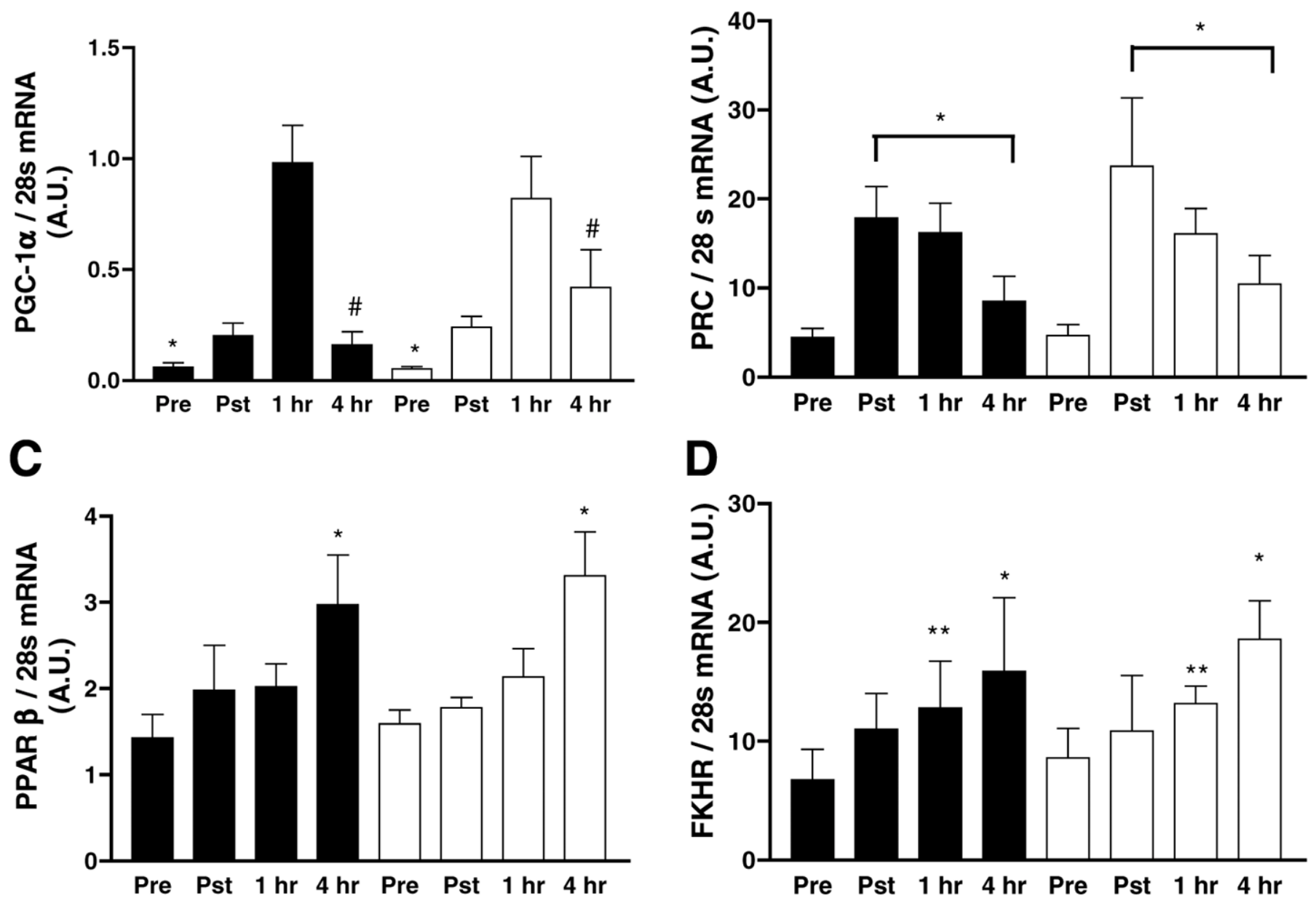

D

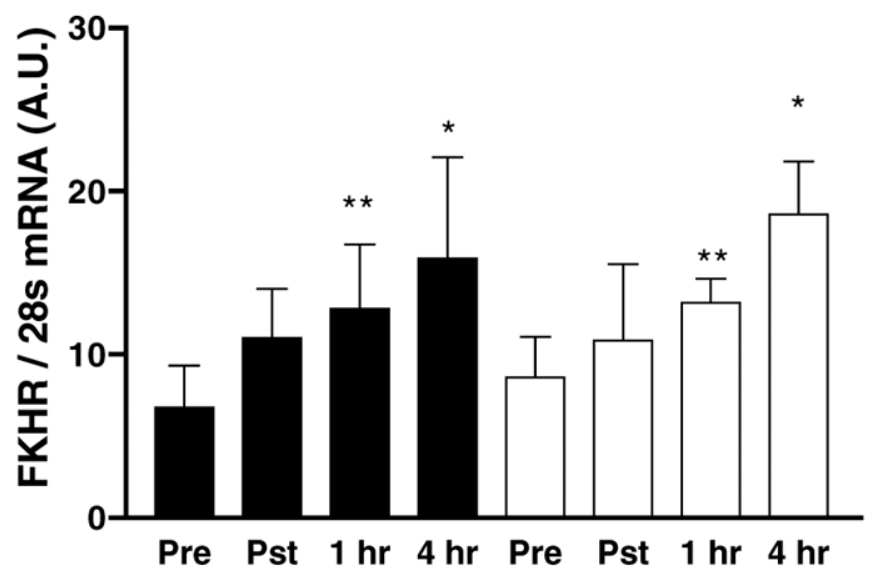

E

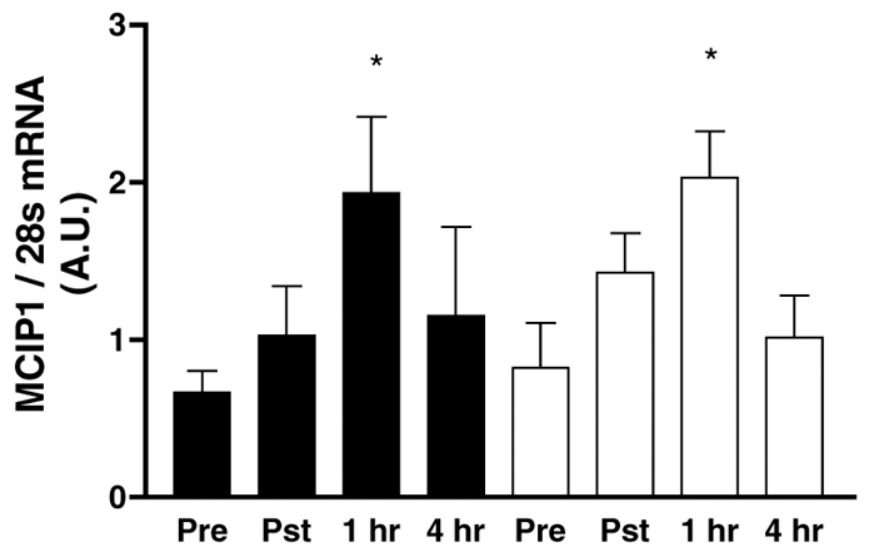

Figure 1. Gene expression of metabolic transcription factors measured pre- and post-exercise when performed in the fasted state (black bars) or with glucose ingestion (white bars). A) PGC-1 $\alpha$; **Pst and $1 \mathrm{~h}$ are significantly different from pre-exercise $(P<0.01)$; \#4 h is significantly lower than $1 \mathrm{~h}$ post-exercise $(P<0.01)$. B) PRC; **Pst, 1 and $4 \mathrm{~h}$ are significantly different from pre-exercise levels $(P<0.01)$. C) PPAR $\beta / \delta ; * * 4 \mathrm{~h}$ is significantly different from pre-exercise levels $(P<0.01)$. D) FKHR; **4 h is significantly different from the other time points $(P<0.01)$; $* 1 \mathrm{~h}$ is significantly different from pre-exercise levels $(P<0.05)$. E) MCIP1; $* 1 \mathrm{~h}$ is significantly different from all time points levels $(P<0.05)$. 
Fig. 2

A

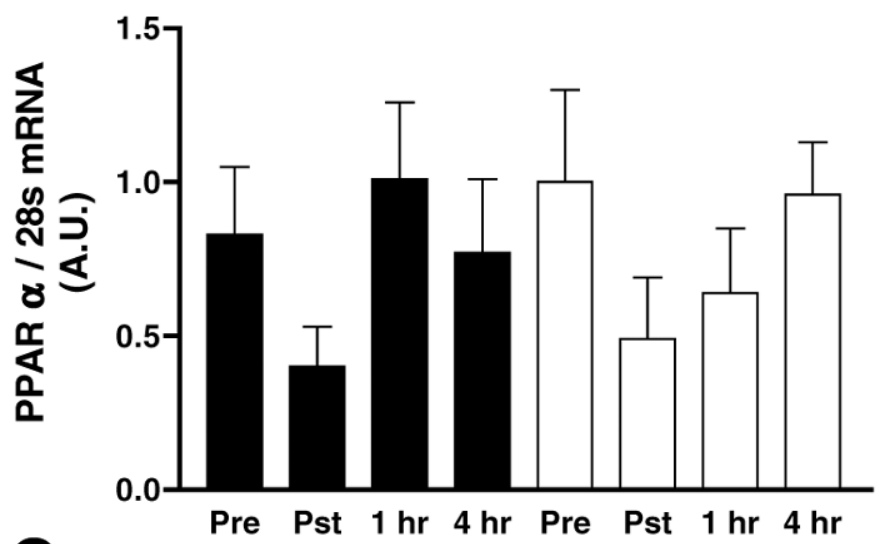

C

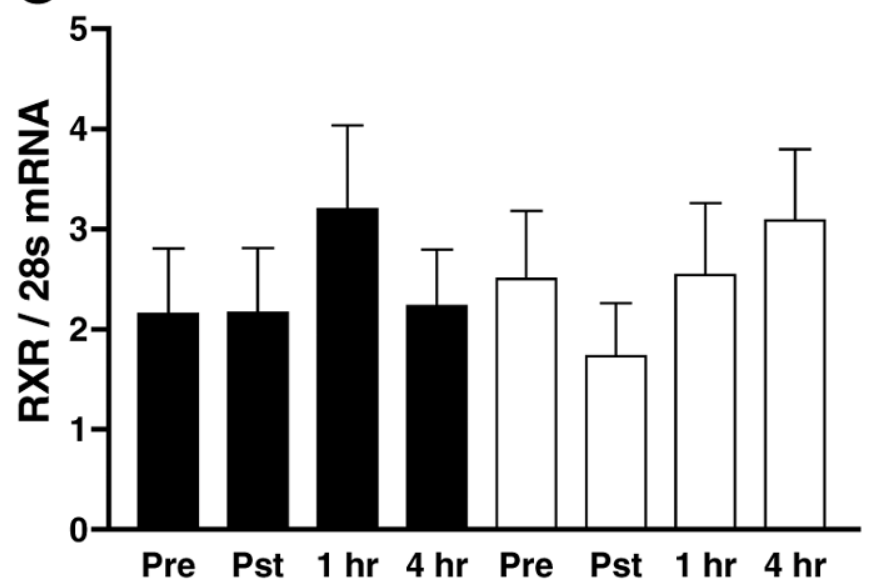

B
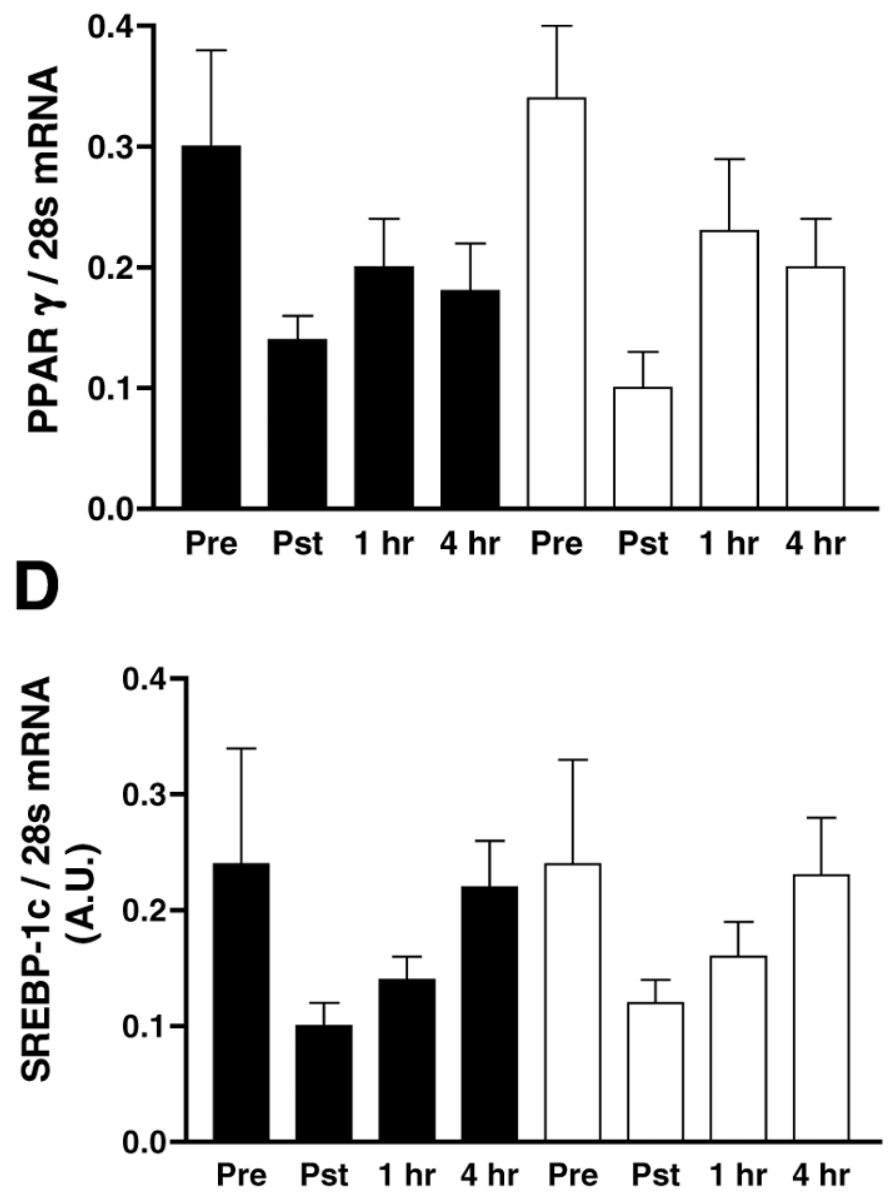

Figure 2. Gene expression of metabolic transcription factors measured pre- and post-exercise when performed in the fasted state (black bars) or with glucose ingestion (white bars). $\boldsymbol{A}) \operatorname{PPAR} \alpha ;(\boldsymbol{B}) \operatorname{PPAR} \gamma,(\boldsymbol{C}) \mathrm{RXR} \alpha ;(\boldsymbol{D})$ SREBP-1c. There were no significant differences for these genes. 